Katarina Marinčič

UDK 821.163.6.09Mihelič M.:81'255.4=163.6=133.1

Univerza v Ljubljani

DOI: $10.4312 /$ vestnik.7.27-36

Filozofska fakulteta

kmarincic@gmail.com

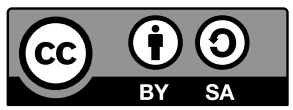

\title{
PISATELJICA, PREVAJALKA IN PREVAJALKA: NOVELA AMY MIRE MIHELIČ V PREVODU ELZE JEREB
}

\section{PISATELJICA, KI PREVAJA, PREVAJALKA, KI PIŠE}

Mira Mihelič, pisateljica, prevajalka, v začetku šestdesetih let dvajsetega stoletja predsednica Društva slovenskih pisateljev, nato dolgoletna predsednica slovenskega centra PEN ter v sklepnem obdobju življenja tudi podpredsednica mednarodnega PEN, je zapustila opus, ki ga lahko brez strahu pred pretiravanjem opišemo s pridevnikom osupljiv. Natančneje: zapustila je $d v a$ opusa, pisateljskega in prevajalskega.

Kot pisateljica je bila Mira Mihelič predvsem romanopiska. Literarni zgodovinarji v njenih delih razbirajo sledove evropskega naturalističnega in socialnorealističnega romana, močan vpliv družinskih sag zgodnjega 20. stoletja, pa tudi elemente (neo)romantičnega zgodovinskega in »ženskega« romana (prim. GACOIN MARKS 2003). Zdi se, da ji je bila od vseh izrazov najbližja dolga, v polnem pomenu besede epska forma, v nekoliko manjši meri dramatika (za dramo Ogenj in pepel je leta 1949 prejela Prešernovo nagrado); novelistika ima v njeni literarni zapuščini, vsaj na prvi pogled, razmeroma skromno mesto. Branko Hofman v spremni besedi k izboru krajše proze Mire Mihelič, ki je izšel v sklopu njenih izbranih del, med drugim zapiše:

\begin{abstract}
/.../ bolj kot iz njenih izjav je razvidno iz njenega ravnanja, da je novelistika ni pritegovala s tolikšno močjo kot romanopisje in dramatika, saj najdemo v pisateljičini bogati knjižni beri samo Malo čarovnico, zbirko štirih med seboj povezanih novel, čeprav je imela gradiva za več novelističnih knjig./.../Zavračala je misel, da bi to zajetno in izpovedno dragoceno pisateljsko žetev kdajkoli pregledala, pretehtala in izdala. Pri tem je navajala najrazličnejše razloge: od naključnega nastanka posameznih tekstov do skepse, da ni za novelistiko posebnega zanimanja med slovenskimi bralci (HOFMAN: 261-2).
\end{abstract}

Ob tem velja pripomniti, da zbirka novel Mala čarovnica, v kateri je izšla tudi novela Amy, zagotovo sodi med pisateljičine najboljše, oblikovno in vsebinsko najizvirnejše knjige; vsaj majhen del te odličnosti se bo morda pokazal skozi našo kratko analizo. 
Epiki, torej daljšim in zelo dolgim pripovednim besedilom, je bila Mira Mihelič zavezana tudi kot prevajalka. Res je, da so prevajalske izbire že po definiciji manj svobodne od pisateljskih. Mira Mihelič se je zagotovo marsikaterega prevoda lotila po naročilu ali iz požrtvovalnosti, z namenom, zapolniti vrzel. Pa vendar: očitno je čutila svoje posebno poslanstvo v zapolnjevanju velikih vrzeli. Leta 1961, ko je izšla novelistična zbirka Mala čarovnica, je imela pisateljica-prevajalka poleg vrste izvirnih romanov med drugim že za seboj prevod Dickensovega Velikega pričakovanja (Great Expectations) in Puste hiše (Bleak House), pa Fieldingovega Toma Jonesa ter - ta prevod omenjamo zaradi vsebinskih afinitet z novelo Amy - Vnukov Louisa Adamiča. Prevod Dickensovih Pickwickovcev, ki ji je prinesel Sovretovo nagrado, je izšel leta 1962.

Poleg Sovretove je Mira Mihelič prejela tudi Župančičevo ter dvakrat Prešernovo nagrado (drugo, leta 1983, za življenjsko delo). Seznam nagrad lepo dopolnjuje bibliografijo: Mira Mihelič je bila za svoje garaštvo in zavezanost literaturi deležna »ustreznega priznanja«. Takole denimo beremo v biografskem zapisu Zlate Cognard (Konjar), ki uvaja francoski prevod novele Amy v antologiji Nouvelles slovènes (1969):

Elle a conquis, sans aucun doute, l'une des premières places parmi les femmes écrivains slovènes. Elle peint surtout la crise et la décadence de la grande bourgeoisie slovène avant et pendant la guerre. Ses portraits de la femme contemporaine, et les multiples variantes de sa lutte pour conquérir une place dans la société, sont fort réussis. Certains de ses personnages abordent sous un éclairage nouveau la pensée et la sensibilité féminines (NOUVELLES SLOVÈNES: 222).

Če se nekoliko pošalimo: navedena notica, ki tudi sicer močno poudarja »žensko pisavo« Mire Mihelič, postavi avtorico na eno vodilnih mest med slovenskimi (ženskimi) pisateljicami; izbor besedil, objavljenih v antologiji, pa priča o tem, da se je Mira Mihelič pravzaprav prebila med (moške) pisatelje; poleg njene Amy najdemo v antologiji še novele Ivana Cankarja, Juša Kozaka, Prežihovega Voranca, Miška Kranjca, Danila Lokarja, Andreja Hienga, Bena Zupančiča in Lojzeta Kovačiča.

Ob dvojnih priznanjih in dvojnem občudovanju pa se nam, najbrž zlasti iz zgodovinske perspektive, postavlja vprašanje, ki nehote zveni otožno. Je bila Mira Mihelič večja (kot) pisateljica ali (kot) prevajalka? Bi jo kot pisateljico morda bolj cenili, če bi ne bilo njenega prevajalskega opusa? Odgovor nam narekuje neizprosna logika: Mira Mihelič je prevajala tako pomembne avtorje, da so njena izvirna dela ob tem preprosto morala ostati v senci. Še neposredneje povedano: ravno zato, ker se je prevajanja lotevala z umetniškim čutom, so knjige, ki jih je prevedla, večinoma (še) boljše in celo za slovenski prostor pomembnejše od njenih izvirnih del. Skromnost, ta narobe obrnjen napuh, ki ga Mira Mihelič s tako ganljivo lucidnostjo izpričuje v svoji avtobiografiji, najbrž izvira tudi iz dolgoletnega druženja z velikani: 
Morda bi bila lahko zadovoljna sama s seboj, pa nisem bila in še danes nisem. In morda bi mi lahko kdo rekel: Prevelika skromnost je narobe obrnjen napuh. Toda natanko se zavedam, da nisem nikoli prestopila tiste meje, ki loči dobro povprečje od nadpovprečnega, in če sem kdaj, v začetku svoje pisateljske poti, imela pred seboj velike cilje, sem se morala sprijazniti s tem, da sem takšna, kakršna sem, in da ne morem biti niti boljša niti slabša - na srečo nočem biti bolj$\check{s} a$, kakor sem, česar o mnogih mojih tovariših pisateljih ni mogoče trditi, pa naj mi ne zamerijo (MIHELIČ 1985: 204).

Gornje dileme v razpravi, posvečeni prevajalskemu opusu Mire Mihelič, vsaj posredno razreši Nike Kocijančič Pokorn, ki opozori na paradoks: prevodi in prevajalci se le izjemoma prebijejo v literarne in kulturne zgodovine posameznih narodov, pri tem pa zagotovo igrajo ključno vlogo pri razvoju sleherne književnosti in kulture. Zapisano je, pripominjamo mi, splošna resnica, a to vse premalo priznano resnico je mogoče, kot pokaže N. Kocijančič Pokorn, ob primeru Mire Mihelič še posebej prepričljivo utemeljiti: prevajalka Mira Mihelič ni le posredovala pomembnih del angleške, ameriške, nemške in francoske književnosti slovenskim bralcem, temveč je ob tem tudi (so)oblikovala slovenski knjižni jezik in vedno znova dokazovala njegovo literarno vsestranskost. Prevajalski opus Mire Mihelič je zagotovo, kot zapiše N. Kocijančič Pokorn, prevodni prispevek $k$ slovenski književnosti (KOCIJANČIČ POKORN 2000: 48). Avtorica pričujočih vrstic bi navedeno misel peljala še nekoliko dlje: pridevnik prevodni lahko izpustimo in prevode Mire Mihelič preprosto štejemo za - prispevek k slovenski književnosti.

(Ob tem drobna osebna pripomba. Razmišljanje o prevajalki, pri kateri sem se kot otrok učila slovensko, pišem za zbornik, posvečen sijajni univerzitetni učiteljici, ki je znala poleg gramatike posredovati tudi duha francoščine: jasnost, doslednost in, nenazadnje, humorni potencial jezika. Da sta se obe dolga leta z veliko požrtvovalnostjo posvečali delu za mednarodno pisateljsko združenje PEN, je le še eno očarljivo naključje.)

\section{NOVELA AMY}

Novela Amy pripoveduje o mladi ženski, ki se v obdobju po drugi svetovni vojni iz Združenih držav Amerike vrne v Slovenijo, domovino svojih staršev. Pripoved je večplastna, vsebinsko, jezikovno in pripovednotehnično ambiciozna. Pisateljica se nikakor ne odpoveduje natančni (klasično realistični) opredelitvi družbenozgodovinskih okoliščin, obenem pa si prizadeva za poglobljeno psihološko analizo, na več mestih z modernistično obarvanimi posegi v protagonistkin spomin, od alkohola skaljeno zavest in podzavest.

Kombinacija družbenega in psihološkega realizma se morda ne izide povsem, razlog za ta delni neuspeh pa bržkone tiči v izbiri prvoosebne pripovedne tehnike. Zgodbo spremljamo skozi doživljanje naslovne junakinje, natančneje skozi njen natrgani in obenem 
neprekinjeni »pogovor« z očetom: dialog, ki je pravzaprav (notranji) monolog, saj je oče junakinja ga ves čas mrzlično nagovarja z dad - že mrtev in je za zgodbo pomemben predvsem kot pobudnik vračanja, oziroma je spomin nanj pobuda za vrnitev.

Amy se v domovino odpravi, da bi uresničila očetove sanje, pravzaprav življenjsko obsesijo: nekoč se bo bogat in ugleden vrnil tja, od koder je moral ponižan oditi. Dad je bil, kot izvemo, v Sloveniji premožen tovarnar; obubožal je zaradi kvartopirskih dolgov, nato emigriral, da je ušel zaporu. Zadoščenja, po katerem je hlepel, ni nikdar dosegel: do smrti je ostal v Ameriki, do smrti proletarec.

Tudi zadoščenje, ki ga doseže Amy, je le polovično, ali še manj kot to, je lažno. V deželi, v katero se junakinja vrača, ni več tovarnarjev: življenjski slog, ki ga je bil prisilno zapustil $\mathrm{dad}$, je v stari domovini prisoten le še kot popačen odmev, karikatura. Predvsem pa se Amy ne vrača kot bogatašinja, tak je le zunanji vtis, ki ga, pa še to le začasno, napravi v povojnem socialističnem okolju.

Osebna zgodba, celo bežna ljubezenska avantura, ki jo med obiskom v domovini doživi junakinja, je tesno vpeta $\mathrm{v}$ zgodovinske okoliščine. Junakinjin monolog - nagovor mrtvemu očetu je tako s psihološkega stališča ponekod preobložen s stvarnimi podatki; pleonastično, vsaj v izbrani formi »natrganih spominov v pogovoru z očetom《, denimo učinkujejo pojasnila o družinski usodi:

Za teboj vije roke ma, tvoja vse življenje nekoliko zaničevana in zapostavljena žena, ker se ni rodila v tako imenitni hiši kakor ti. Njen oče je bil navaden zidar in čutila je, da zelo zaostaja za teboj, to je čutila tako krepko, da sem se tudi jaz navadila gledati svojo mater nekam prizanesljivo in z rahlim prezirom, dokler ni vsa siva in zagrenjena prezgodaj umrla. Ma torej vije roke za teboj, jih sklepa in se vrti v čudnem poslovilnem plesu, nato pa odhaja od naju med razpoke $v$ steni najine velike sprejemnice, odhaja kakor Miles, ki ga spremlja moj ljubček Jolly, in Jollyjev plašč je težji od Milesovega-zaradi pištole v žepu (MIHELIČ 1986: 94-95).

Amyina »predzgodovina« učinkuje naravno tam, kjer je njeno naravno mesto: v dialogih z bratrancem Martinom, ki zgodbo posluša prvič:

Gledala sem Martina in čutila, kako mu roke bolj in bolj trepečejo orog mojega pasu.

»In tudi jaz sem se hotela vsaj enkrat v življenju postaviti, enkrat v življenju zaigrati vlogo, ki si jo je moj ubogi dad sanjal zame, oh, samo enkrat... Po njegovi smrti sem dobila zavarovalnino in tisti denar potem porabila za potovanje $v$ stari kraj. Zdaj pa si želim, da bi ne bila prišla nikoli sem, temveč da bi se spet lahko vrnila v Ameriko, toda ne v sedanji čas, temvečv tistega, ko so še živeli ma, dad in moj veliki brat Miles ... mogoče sem bila takrat, ne da bi bila sama vedela, 
srečna ... Ko mi je bilo sedemnajst let, smo se preselili iz Clevelanda v New York, poskušali smo nekaj več zaslužiti in živeti dostojno. Nato so fantje, s katerimi se je povezal Miles, mojega brata ubili. Potem je umrla od žalosti moja mama. Potem še dad. Tudi fanta sem imela. Ime mu je bilo Jolly ... Bil je Milesov prijatelj. Eden tistih, ki so Milesa ...«(Ibid., 120-121).

Zanimivejši, slogovno in psihološko verjetnejši pa je tisti del pripovedi, v katerem se nam Amy kaže kot poslušalka, pasivna posnemovalka zunanjega sveta. Tako denimo v angleških stavkih, ki ji polzijo v pripoved in so vsi izrazito klišejski, priučeni. Nekaj skladenjsko zanimivejših primerov:

- Samo še požirek, honey! (Ibid.: 83).

- Take it easy, bi rekel Miles. Oh, dad, zdaj nimam niti te hiše več to think about (Ibid.:84).

/.../ moja babica iz starega kraja, prav tako odlična lady kot mrs. Astor in njene družice iz high society (Ibid.: 85).

/.../ midva nisva bila nikoli tako mlada, ker smo preživeli toliko let v apartment housu na Bludgeon Roadu (Ibid.: 87).

$V$ hotelu sem se skrbno napravila in si obleka najlepšo obleko, za katero je rekel Jolly, da sem v nji a princess.

But you're a beautiful girl, Amy, lepo dekle si, Amy (Ibid.: 91).

Pragmatična zahteva, naj angleščina ne bo pretežka za slovenskega bralca, se tu lepo ujame s pasivnim, za vtise in sugestije odprtim značajem junakinje.

Najboljši del novele pa je osrednja epizoda: $z$ dialogi gosto pretkan opis improvizirane zabave, ki jo priredijo, ko Amy napove, da bo plačala obnovo rodbinske vile. Dogajanje, kot ga lovijo junakinjine oči in predvsem ušesa, spominja na zolajevske gostije: nenadno obilje pravzaprav razkrije revščino, slavje je napoved propada. Pomembno funkcijo v tem delu pripovedi imajo dialogi z ostanki predvojne (meščanske) nemščine, zapisane v popačeni (»fonetični«) obliki. Replike, ki so obenem odmev nekdanje domačnosti in znamenje sprevrženosti, grotesknega razkroja:

»Napekla sem piškotov, « je rekla. »Te so gnedige frau posebno radi jedli.» (Ibid.: 99).

»Majngot, naša dušica so prišli! In kako lepi so-elegantni!« (Ibid.: 102).

"To je buvje, ekstra draj."

»Draj ali cvaj, zdajle si ga Bertlček privošči, «je zamomljal čevljar (Ibid.: 114).

»Majngot, kaj bodo rekli heršaften, ki naju gledajo, kar nerodno mi je, res.»

(Ibid.: 115). 
Estetsko in psihološko prepričljivi so tudi opisi habitata, zlasti vile, ki v junakinjini duševnosti zaseda posebno mesto. Zanimivo je, da se prav v teh (pogojno rečeno najbolj »literarnih«) delih besedila najizraziteje pokaže slogovna posebnost Mire Mihelič, na katero ob primerih iz njenega prevajalskega opusa opozarja tudi Nike Kocijančič Pokorn: za slovenščino nenavadno pogosta raba deležnikov in deležniških struktur (prim. KOCIJANČIČ POKORN 2000, 50-52). Ob tem se poraja misel, da gre - tako pri pisateljici kot znotraj zgodbe pri junakinji - za nekakšno kontaminacijo s tujim jezikom. Je Mira Mihelič pripoved svoje Amy z notrajim ušesom morda slišala v angleščini, od katere so nato, kot nekakšen namig, a clue, ostale posamezne povedi, vključno s tisto, v katero novela tudi izzveni: In vendar, dad, nimam zdaj niti te hiše več to think about (Ibid.:123)?

Tako je ostal za menoj moj dom, ki ni bil nikdar moj - črna nazobčana razvalina, odbijajoča se od zvezdnatega neba skoraj tako grozljivo, kakor se je nekoč ločila od umetno presvetljene noči temnejša gmota stare zapuščene tovarne z razbitimi okni in s plevelom, ki mi je segal do pasu -žalostna podrtija, v kateri sem kot otrok gledala nekakšno pošast, prežečo na nas onkraj Denver \& Rio Grande železnice, lesketajoče se s šestimi pari tračnic v neprijazno mestno četrt, kjer smo tedaj stanovali.

Tekla sem in tekla, medtem ko se je ulivala za menoj poslednja lisa mesečine z vzdihi vetra čez podrto hišo, božajoč plaho votline njenih nekdanjih oken, iz katerih je mrlikala luč ugašajočega lampijona, ki vem, da so se okrog njega lovile vešče in si smodile krila ob njegovi umirajoči sveči. Razvalina je ostala za menoj z visokim črnim dimnikom, štrlečim kvišku kakor prst, ki kaže v nedostopni obok nad nami, posut z zlatim in srebrnim utripanjem krožečih svetov. Daj mi še kaj popiti, honey... Tako bo nekoč, mogoče kmalu, ostala nekje za nami poslednja hiša, dvigajoča se z ostanki svojih zidov v ravnodušno vrteči se molk, obljudena samo še s sencami - nema priča, da so tukaj živeli ljudje, ki ni zdaj niti sledu več po njihovem grenkem prahu (Ibid.: 83).

\section{$3 A M Y V$ FRANCOŠČINI}

Naj na tem mestu preidemo od originala k francoskemu prevodu ${ }^{1}$.

Elza Jereb deležniške strukture skrbno in elegantno prenese $\mathrm{v}$ francoščino. Besedilo tako ohrani ritem in poetično lepoto, izgubi morda le nekaj »nenavadnosti«, eksaltiranosti izvirnika - vendar je ta izguba tako malenkostna, da se iskanje drugačnih rešitev skoraj ne zdi smiselno. (Zgolj kot spekulacija: podobno presenetljivo (in rahlo okorno), kot v slovenščini učinkuje veliko število deležnikov, bi v francoščini morda povečano število

1 Izdajatelji antologije pojasnjujejo, da sta pri nastajanju prevodov sodelovala Zlata Cognard in Christian Bernard, ki sta dala dokončno obliko à la traduction littérale faite en Yougoslavie. Velika zvestoba izvirniku, ki jo opažamo v prevodu novele Amy, nas navaja k sklepu, da je bil prevod E. Jereb deležen minimalnih redaktorskih posegov. 
odvisnikov. S precejšnjo gotovostjo pa lahko zapišemo, da bi ciljni, torej francoski bralec, takšen odmik pripisal nespretnosti prevajalke, ne morda jezikovni maniri ali celo slogovni karakterizaciji literarnega lika. Še več: kopičenje sedanjih deležnikov v navedenem odlomku je očitno prehudo celo za francosko uho: prevajalka se pri eni od struktur - visokim črnim dimnikom, štrlečim kakor prst - s pretanjenim ritmičnim posluhom odloči za odvisnik, ki bi, resnici na ljubo, tudi v slovenščini zvenel lepše od deležnika: la haute cheminée qui se dressait comme un doigt.

Ainsi était restée derrière moi cette maison qui ne fut jamais mienne-sombres ruines dentelées, se reflétant, horrifiantes, contre le ciel étoilé, tout comme autrefois, contre la nuit, artificiellement éclairée, se dressait la masse sombre de l'usine abandonnée aux carreaux brisés, entourée de mauvaises herbes m'arrivant jusqu'aux hanches - tristes ruines où, enfant, je voyais une sorte de monstre, nous épiant de derrière le chemin de fer »Denver and Rio« qui menait, avec ses six paires de rails luisants, vers le quartier maussade où nous habitions alors.

Je courus longtemps tandis que sombrait derrière moi le dernier rayon de clair de lune, accompagné de gémissements du vent, effleurant les murs, caressant les creux de ses anciennes fenêtres où clignotait la lumière d'un petit lampion presque éteint, autour duquel, je le savais, les papillons de nuit avaient dansé et y avaient brûlé leurs ailes. Les ruines étaient restées derrière moi avec la haute cheminée qui se dressait comme un doigt vers la route inaccessible parsemée de mondes scintillants d'or et d'argent. Donne-moi encore quelque chose à boire, Honey... Ainsi, un jour peut-être proche, il ne restera après nous qu'une dernière maison dressant les restes de ses murs dans le silence s'écoulant avec indifférence, une maison peuplée uniquement d'ombres - témoin muet des hommes dont il n'est plus resté la moindre trace de leur poussière amère (NOUVELLES SLOVÈNES: 225).

Zvestobo originalu Elza Jereb ohranja tudi ob transponiranju angleških delcev besedila $v$ francoščino (navajamo iste primere kot zgoraj). S skladenjsko prilagodljivostjo teh elementov ima, razumljivo, manj težav kot pisateljica $v$ slovenskem originalu. $\mathrm{V}$ enem od navedenih primerov ( $v$ apartment housu na Bludgeon Roadu) pa se, kot vidimo, odloči za poenostavitev:

Un petit coup, Honey! (Ibid., 225)

Take it easy, aurait dit Miles. Oh! Dad, je n'ai même plus cette maison to think about (Ibid., 226).

/.../ nous n'avons jamais été si jeunes car nous avons passé trop d'années sur la Bludgeon Road (Ibid., 228).

/.../ ma grand-mère de l'ancienne patrie, une lady aussi distinguée que Mrs. Astor et ses amies de la high society (Ibid., 227). 
J'avais mis ma plus jolie robe, dans laquelle j'étais, comme disait Jolly, a princess. - »But you're a beautifull girl, Amy. - Tu es une jolie fille, Amy...« (Ibid, 231).

Nekateri res drobni odmiki od izvirnika pripomorejo $\mathrm{k}$ jasnosti in tekoči berljivosti francoskega besedila. Tako denimo odločitev za veliko začetnico in poševni natis pri ponavljajoči se besedi »dad«, ki jo Mira Mihelič zapisuje z malo začetnico in pokončno (medtem ko se $m a$, kot lahko vidimo tudi v enem zgoraj navedenih odlomkov, pojavlja v poševnem natisu).

K poenotenju in jasnosti teži tudi odločitev za prevajanje popačenih (v slovenskem izvirniku »po izgovorjavi transkribiranih«) nemških besed, ki jih prevajalka zapisuje v knjižni nemščini. Zgoraj navedeni primeri se tako v francoskem prevodu berejo:

- J'ai fait quelques biscuits, dit-elle. La gnädige Frau aimait particulièrement ceux-ci (Ibid.: 236).

- Mein Gott, notre petit ange est arrivée! Qu'elle est mignone, qu'elle est élégante! (Ibid.: 238)

- C'est de l'extra dry!

- Drei ou zwei, peu importe, Bertl peut s'en payer maintenant, marmonna le cordonnier /.../ (Ibd.: 246).

- Mein Gott, que va dire la Herrschaften (sic!) qui nous regarde, je suis vraiment gênée (Ibid.: 248)².

Osnovni pomen navedenih povedi v obeh zapisih ostaja enak, se pa v francoskem prevodu (oziroma v knjižni nemški varianti) zagotovo izgubi velik del družbenozgodovinskih konotacij, pa tudi komičnosti. Morda bi se vendarle našla še kaka druga rešitev. Francoski književnosti karikirano fonetično zapisovanje nemškega jezika (ali naglasa) navsezadnje ni tuje: spomnimo se samo na Balzacovega Nucingena in njegov znameniti akcent:

Esder, dit-il en lui lâchant la main, et la repoussant avec un léger mouvement d'humeur, fus ne m'égoudez bas! (Cit. BEM 2009: 116; ibid.: 115, o dosledni rabi poševnega tiska).

S tem nočemo reči, da bi bila judovsko-alzaška francoščina, ki jo Balzac polaga v usta bankirju Človeške komedije, prevodna ustreznica za govorico slovenskih (malo)meščanov 19. in prve polovice 20. stoletja. Prevod bi nemara kazalo iskati po analogiji z Balzacovo in podobnimi karikaturami, v fonetičnem zapisu, iz katerega bi lahko tudi francoski bralec zaznal jezikovno spakedranost izvirnika.

Kritično pripombo smo z mirno vestjo prihranili za konec, in to je seveda pomenljivo. Da nas Mira Mihelič in Elza Jereb navajata k razmišljanju o tako specifičnih, tako parcialnih problemih, je dokaz kvalitete njunih besedil. Novela Amy je delo pisateljice, ki se je

2 Nepomembna, anekdotična pripomba: die Herrschaften, v nemščini in v originalu Mire Mihelič samostalnik v množini, s pomočjo lažno prijateljskega slovničnega škrata - ali nemara s pomočjo prevnetega korektorja, ki v naglici določi, da je die ženska oblika? - v francoščini dobijo člen za ženski spol ednine. 
ob oblikovni in vsebinski ambicioznosti znala sprijazniti tudi s kakim delnim porazom. V francoskem prevodu ji ob bok stopi prevajalka, ki je natančnost in zvestobo izvirniku znala združiti z občutkom za slog, zlasti z nezgrešljivim posluhom za ritem.

\section{BIBLIOGRAFIJA}

BEM, Jeanne (2009) L'allemand comme langue imaginaire chez Victor Hugo et Balzac: Alternative francophone, vol.1, 2, 107-119.

GACOIN MARKS, Florence (2003) Iznenada se je naveličala romanov in otožnih blodenj: Obraz v zrcalu Mire Mihelič v luči evropskega romanopisja. Slovenski roman (Obdobja 21). Ljubljana: Center za slovenščino kot drugi/tuji jezik pri Oddelku za slovenistiko Filozofske fakultete, 499-509.

HOFMAN, Branko (1986) Človečnost ali nečlovečnost. v: Mira Mihelič: Mala čarovnica; Novele in črtice. Ljubljana: Cankarjeva založba, 260-271.

KOCIJANČIČ POKORN, Nike (2000) Prevajalsko delo Mire Mihelič : prevodni prispevek slovenski književnosti. v: Mavrica nad zapuščino: Mira Mihelič, 1912-1985. Ljubljana: SC PEN, 48-53.

MEJAK, Mitja (ed.) (1996) Nouvelles slovènes. Paris: Seghers.

MIHELIČ, Mira (1985) Ure mojih dni. Murska Sobota: Pomurska založba.

MIHELIČ, Mira (1986) Mala čarovnica; Novele in črtice. Ljubljana: Cankarjeva založba.

\section{POVZETEK}

\section{Pisateljica, prevajalka in prevajalka}

Članek obravnava prevod novele Amy pisateljice Mire Mihelič, ki ga je za francosko antologijo Nouvelles Slovènes (1969) pripravila Elza Jereb. Besedilo, v katerem se klasične pripovedne tehnike prepletajo z zametki modernističnih prijemov, ima tudi nekaj skladenjskih posebnosti, med katerimi najbolj izstopa za slovenščino nenavadno pogosta raba deležnika in deležniških struktur. Prevod odlikujeta zvestoba in natančnost, pa tudi izrazit posluh za ritem. Skladenjska in nekatera druga drobna odstopanja nikjer ne spreminjajo pomena izvirnika, temveč, nasprotno, ta pomen ohranjajo in utrjujejo. Preprost poseg, kot je denimo poenotenje kurzivnega zapisovanja določenih izrazov, brez nasilnega poenostavljanja pripomore k jasnosti besedila. Prevajalska rešitev, ki (kvazi) fonetični zapis govorjene nemščine pretvarja v knjižno različico, pa nas navaja k razmisleku o alternativnih možnostih, ki bi morda v polnejši meri ohranile družbenozgodovinske konotacije in komični naboj izvirnika.

Ključne besede: Mira Mihelič, Elza Jereb, slovenska književnost v prevodih 


\section{ABSTRACT}

\section{A Writer, a Translator and a Translator}

The article deals with the French translation of the short story Amy by the Slovenian writer Mira Mihelič, made by Elza Jereb for the anthology Nouvelles slovènes (Paris, 1969). The original text, a classical narrative involving some modernist strategies, presents a syntactical feature rather unusual in Slovenian (although typical of the author Mira Mihelič): a very frequent use of participles and participial structures. Elza Jereb's translation is accurate and precise, preserving not only the basic meaning but also the stylistic qualities, particularly the internal rhythm of the original. Some slight changes (such as for example a more consequent and logical use of italics) render the text accessible to the French reader without undue simplifications. The only part of the original that seems to get lost in translation are some minor parts of the dialogue: the phonetically transcribed provincial German of the original, rich in social connotations, is translated into standard literary German, thereby losing some of its sociohistorical implications as well as some of its comical potential.

Key words: Mira Mihelič, Elza Jereb, Slovenian literature in translations 